\title{
Penggunaan layanan open library dalam memenuhi kebutuhan informasi mahasiswa Telkom University
}

\author{
Fikri Dwi Oktaviani1, Pawit M. Yusup ${ }^{2}$, Ute Lies Siti Khadijah ${ }^{3}$ \\ 1,2,3Program Studi Ilmu Perpustakaan Universitas Padjadjaran \\ Jl. Raya Bandung-Sumedang Km. 21, Jatinangor, Sumedang, Jawa Barat 45363 \\ E-mail: 1fikri.oktavial@gmail.com, 2pawitmy@gmail.com, ${ }^{3}$ ute.lies@unpad.ac.id
}

Received: July 2017; Accepted: April 2018; Published: May 2018

\begin{abstract}
This study aimed to find out the use of open library digital library services in meeting the information needs of Telkom University students. The study used the qualitative method with case study approach. Data collection techniques were conducted through interviews with Telkom University students, observation, and literature study. Study results showed that the initial stage was based on the motivation and goals arising from self-awareness and the need to increase knowledge in completing tasks and scientific works (thesis/TA). Browsing began with authentication using an SSO account (Igracias), and information retrieval began with using a simple search facility. Students also used the internet to access various other sources with the Google search engine to further enrich the required information. Then, At the formulation stage, students conducted brainstorming by learning and understanding the problem-solving process related to the appropriate topic and discussing it with friends, lecturers, or people who were considered understandable and could be invited to discuss related topics that were being deepened. The collection stage was done by downloading the file and storing it in their laptop folder. At the presentation stage, students would feel satisfied after getting the information so it is possible to do monitoring. The presentation was performed in the form of writing a new document or as a complement in both the completion of lecture assignments (proposal and paper) as well as the writing of scientific papers (thesis/TA).
\end{abstract}

Keywords: Usefulness; Digital library; Information needs; Open library

\begin{abstract}
Abstrak
Penelitian ini bertujuan untuk mengetahui penggunaan layanan perpustakaan digital open library dalam memenuhi kebutuhan informasi mahasiswa Telkom University. Metode penelitian yang digunakan adalah metode kualitatif dengan pendekatan studi kasus. Teknik pengumpulan data dilakukan melalui wawancara pada mahasiswa Telkom University, observasi, dan studi pustaka. Hasil dari penelitian ini diketahui bahwa pada tahap permulaan didasari atas motivasi dan tujuan yang timbul atas kesadaran diri dan kebutuhan untuk menambah pengetahuan dalam menyelesaikan tugas kuliah maupun karya ilmiah (skripsi/TA). Penjelajahan diawali dengan autentikasi menggunakan akun SSO (Igracias), dan pencarian informasi dimulai dengan menggunakan fasilitas pencarian sederhana. Mahasiswa pun memanfaatkan internet untuk mengakses berbagai sumber lain dengan mesin pencari google untuk lebih memperkaya informasi yang dibutuhkan. Selanjutnya pada tahap perumusan, mahasiswa melakukan brainstorming dengan mempelajari dan memahami proses penyelesaian masalah terkait topik yang sesuai dan mendiskusikannya kepada teman, dosen, atau orang yang dianggap paham dan bisa diajak diskusi terkait topik yang sedang diperdalam. Tahap pengumpulan dilakukan dengan mengunduh file-file dan menyimpannya di folder laptop mereka. Pada tahap penyajian mahasiswa Telkom University akan merasa puas setelah mendapatkan informasi sehingga memungkinkan untuk melakukan monitoring. Penyajian dilakukan dalam bentuk penulisan dokumen baru atau sebagai pelengkap baik dalam penyelesaian tugas perkuliahan (proposal dan makalah) maupun penulisan karya ilmiah (skripsi/TA).
\end{abstract}

Kata Kunci: Penggunaan, Perpustakaan digital, Kebutuhan informasi; Open library 


\section{PENDAHULUAN}

Seiring dengan perkembangan teknologi informasi yang tercipta melalui jaringan interconnection networking (internet), berbagai kemudahan dalam mengakses informasi telah banyak dimanfaatkan oleh individu maupun organisasi termasuk perpustakaan. Permanfaatan teknologi informasi di perpustakaan dapat terlihat dengan digunakannya sistem otomasi perpus-takaan dan perpustakaan digital. Bagi perpustakaan perkembangan teknologi informasi semakin terbuka luas dalam memberikan kesempatan untuk mening-katkan jasa layanan informasi, sedangkan bagi pengguna perpustakaan perkembangan teknologi informasi memudahkan pengguna untuk mencari berbagai informasi dengan cepat.

Open library Telkom University adalah brand untuk Unit Sumber Daya Keilmuan (SDK) dan Perpustakaan Telkom University yang berada di bawah Wakil Rektor III Telkom University. Sejak 2014 SDK dan Perpustakaan Telkom University telah mengembangkan konsep Open library yang terdiri dari 3 (tiga) pokok pemikiran, yakni Open untuk menerima semua jenis knowledge, Open untuk berbagi knowledge dengan knowledge management lain, dan Open untuk siapapun yang ingin belajar. Pengembangan perpustakaan elektronik yang diintegrasikan dengan aplikasi knowledge management, open library Telkom University berkomitmen untuk membuka seluruh sumber pengetahuan yang dimilikinya. Peluncuran "Telkom University open library" yang mana terdiri dari kurang lebih 14.000 tugas akhir, skripsi, dan tesis dapat dimanfaatkan secara online dan gratis bagi semua masyarakat umum dengan mengakses layanan perpustakaan digital open library. Dalam hal ini, Telkom University pun pernah dinobatkan sebagai "Top Contributor" Indonesia One Search (program Perpusnas RI) dengan 85.283 files yang dibagi. Hingga saat ini koleksi yang disediakan oleh perpustakaan open library berjumlah 115.881 eksemplar dengan 72.286 judul (L. S. Rahmawati, wawancara, November 15, 2017).

Perpustakaan digital open library merupakan kolaborasi antara sistem informasi perpustakaan dan sistem knowledge management yang berperan dalam proses pengorganisasian dan penyebarluasan informasi serta berbagai pengetahuan yang berkaitan dengan lembaga atau organisasi yang dikelolanya. Kolaborasi tersebut dapat dimanfaatkan oleh civitas akademika dengan mengakses openlibrary.telkomuniversity.ac.id untuk menelusuri berbagai informasi yang tersedia di perpustakaan.

Openlibrary.telkomuniversity.ac.id mer-upakan alamat yang dapat dikunjungi oleh user untuk memanfaatkan layanan perpustakaan digital open library. Pada tahun 2017, total pengunjung online perpustakaan digital open library berjumlah 144.188 (L. S. Rahmawati, wawancara, November 15, 2017).

Sebagian besar pemustaka civitas akademika Telkom University merupakan mahasiswa yang hidup dan berkembang di era digital. Dengan kata lain mahasiswa Telkom University merupakan bagian dari generasi digital yang memiliki potensi besar sebagai pengguna teknologi perpustakaan. Mahasiswa merupakan kaum akademik yang selalu dihadapkan pada persoalan yang mendorongnya untuk melakukan aktivitas pencarian informasi. Dengan adanya layanan open library, mahasiswa Telkom University mendapatkan manfaat dalam mengakses 
berbagai sumber informasi yang disediakan dengan mudah dan cepat, bahkan tidak perlu datang langsung ke perpustakaan.

Disamping itu, mahasiswa merupakan kaum akademik yang selalu dihadapkan pada persoalan yang mendorongnya untuk melakukan aktivitas pencarian informasi. Dengan adanya layanan open library, mahasiswa Telkom University mendapatkan manfaat untuk bisa akses informasi dengan mudah dan cepat, bahkan tidak perlu datang langsung ke perpustakaan. Kolaborasi yang ada didalamnya memberikan kemudahan penggunaan serta dalam melakukan transaksi yang biasa dilakukan di perpustakaan secara online. Menurut KBBI atau Kamus Besar Bahasa Indonesia Penggunaan yaitu proses, cara, perbuatan menggunakan sesuatu; pemakaian. ("Kamus Besar Bahasa Indonesia (KBBI)," 2017). Jadi penggunaan disini merupakan suatu aktivitas atau kegiatan pemakaian perpustakaan digital open library dengan melalui suatu proses dan cara untuk tujuan tertentu. Penggunaan disini ditujukan lebih kepada civitas akademika yang tak lain merupakan mahasiswa Telkom University. Maka dari itu, sesuai realita dilapangan, timbul pertanyaan terkait yakni bagaimana penggunaan layanan perpustakaan digital open library dalam memenuhi kebutuhan informasi mahasiswa Telkom University.

Adapun tujuan dari kegiatan penelitian ini adalah untuk mengetahui permulaan (inisiasi), seleksi (selection), penjelajahan (exploration), perumusan (formulation), koleksi (collection), dan presentasi (presentation) penggunaan layanan perpustakaan digital open library dalam memenuhi kebutuhan informasi mahasiswa Telkom University.
Pada era teknologi seperti sekarang ini munculah berbagai perpustakaan digital di Indonesia, terutama di lingkungan perpustakaan perguruan tinggi dan khusus (Sulistyo-Basuki, 2001). Perpustakaan digital adalah suatu perpustakaan yang menyimpan konten berupa tulisan, gambar, suara, video dalam bentuk file elektronik dan mendistribusikannya melalui jaringan komputer (Sasongko \& Hartanto, 2015). Perpustakaan digital memberikan kemudahan bagi para pengguna untuk mengakses sumber-sumber elektronik dengan alat yang menyenangkan pada waktu dan kesempatan yang terbatas. Pengguna bisa menggunakan sumber informasi tersebut tanpa harus terikat kepada jam operasional perpustakaan seperti jam kerja atau jam buka perpustakaan.

Terdapat beberapa karakteristik yang menggambarkan tentang perpustakaan digital, karakteristik yang dimiliki oleh perpustakaan digital menurut Savanur dan Nagaraj tahun 2004 dalam (Sasongko \& Hartanto, 2015) yaitu: (1) perpustakaan digital merupakan rekan dari perpustakaan tradisional dalam mengelola bahan koleksi dalam bentuk digital, (2) perpustakaan digital memiliki dan menguasai informasi serta menyediakan akses kepada informasi, (3) perpustakaan digital memiliki struktur organisasi yang terpadu dengan nilai yang konsisten untuk mengakses data, (4) perpustakaan digital bukan hanya sebuah entitas tunggal, tetapi juga dapat memberikan akses terhadap materi digital dan sumber daya dari digital library lainnya, (5) perpustakaan digital mendukung akses yang cepat dan efisien terhadap sumber informasi yang saling terkoneksi dalam jumlah yang besar, (6) 
perpustakaan digital memiliki koleksi yang besar dan bertahan dari waktu ke waktu, koleksi yang terorganisasi dan dikelola dengan baik, memiliki banyak format data, berisi objek dan bukan hanya perwakilan dari objek, dan perpustakaan digital mencakup semua proses dan layanan yang ditawarkan oleh perpustakaan tradisional, meskipun proses tersebut harus direvisi untuk mengakomodasi perbedaan antara media digital dan media cetak.

Mahasiswa merupakan kaum akademik yang selalu dihadapkan pada persoalan yang mendorongnya untuk melakukan aktivitas pencarian informasi, terutama informasi yang dapat menunjang perkuliahannya. Seperti yang diungkapkan oleh Yusup (2010) bahwa "Masyarakat, pelajar, dan mahasiswa misalnya, sangat jelas akan kebutuhannya terhadap informasi, terutama informasi yang berkaitan dengan akademik dan pendidikan. Informasi dalam hal ini bermakna segala jenis data, fakta, ataupun keterangan yang banyak berhubungan dengan tugas-tugas akademik pelajar yang bersangkutan sebagai orang yang sedang melakukan proses kehidupannya, bersekolah (belajar)."

Kebutuhan informasi timbul karena adanya rasa ingin tahu. Rasa ingin tahu seseorang timbul karena ia ingin selalu berusaha menambah pengetahuannya. Setiap orang membutuhkan informasi sebagai bagian dari tuntutan kehidupan, penunjang kegiatan, dan sebagai pemenuhan kebutuhannya. Rasa ingin tahu seseorang timbul karena ia ingin selalu berusaha menambah pengetahuannya. Kebutuhan informasi merupakan suatu keadaan yang terjadi dalam struktur koginisi seseorang yang dirasakan ada kekosongan informasi atau pengetahuan sebagai akibat tugas atau sekadar ingin tahu. Kekurangan ini perlu dipenuhi dengan informasi baru yang sesuai dengan kebutuhannya. (Yusup, 2010)

Katz, Gurevitch, dan Haas dalam (Yusup, 2010) menyatakan bahwa kebutuhan informasi terdiri dari lima katergori, yaitu kebutuhan kognitif, kebutuhan afektif, kebutuhan integrasi personal (personal integrative needs), kebutuhan integrasi sosial (social integrative needs), kebutuhan berkhayal (escapist needs). Sedangkan menurut Guha, Kebutuhan informasi dapat dibagi menjadi 4 bagian yaitu kebutuhan informasi mutakhir (current need approach), kebutuhan informasi rutin (everyday need approach), kebutuhan informasi mendalam (ezhaustive need approach), kebutuhan informasi sekilas (chatting up need approach).

Dalam model pencarian informasi, disebutkan bahwa informasi mempunyai tahapan yang berbeda namun memiliki kesamaan tertentu dalam hal perilaku mencari informasi, hal ini dikemukan oleh Kuhlthau dalam (Yusup, 2010) dengan tahapan dimaksud yakni permulaan (inisiasi), seleksi (selection), penjelajahan (exploration), penyajian (formulation), koleksi (collection), dan penyajian (presentation).

Ada beberapa penelitian terdahulu yang menggunakan konsep sama dengan penulis yakni kebutuhan informasi, namun yang membedakan adalah sudut pandang permasalahan dari setiap peneliti. Misalnya, Penelitian yang dilakukan Herni (2016) dengan judul penggunaan aplikasi single sign-on (SSO) dalam memenuhi kebutuhan informasi mahasiswa Fakultas Peternakan Universitas Padjadjaran fokus kepada permulaan mendapatkan informasi. 
Dilatarbelakangi oleh motivasi dan tujuan, adanya rasa penasaran dan keinginan untuk mendapatkan informasi mengenai fenomena dan isu-isu terbaru yang ada di lingkungan kampus, proses seleksi dari informasi beasiswa ini berkaitan aspek rasional, (exploration) dilakukan dengan mengakses SSO di Fakultas Peternakan Unpad dan membuka jaringan internet lalu http://students.unpad.ac.id. Setelah itu Login Paus id, pada penyajian mereka melakukan klarifikasi informasi dengan cara membahasnya kedalam forum diskusi, bertanya langsung kepada pihak yang bersangkutan, dan mengakses sumber informasi lain, proses koleksi dilakukan dengan cara membagi informasi, dengan cara komunikasi lisan atau melalui media sosial lainnya, dan menyimpan informasi (storing information) di laptop. Hasil dari prosesnya, menimbulkan rasa kepuasaan tersendiri pada diri mahasiswa Fakultas Peternakan Unpad. Adanya rasa puas akan hasil dari informasi yang didapat dari SSO, maka terdapat kemungkinan bagi mahasiswa Fakultas Peternakan Universitas Padjadjaran untuk mengakses kembali SSO Fakultas Peternakan Unpad di kemudian hari. Penelitian ini menggunakan metode Kualitatif pendekatan studi kasus (wawancara, observasi, dan dokumentasi).

Berbeda halnya dengan penelitian yang dilakukan oleh Permana (2016) mengenai proses pendalaman informasi berbasis informasi awal dari LINE @BEM fikom unpad oleh mahasiswa yang memiliki hasil penelitian bahwa semua informan melakukan pendalaman atas informasi yang mereka peroleh dari LINE @BEM Fakultas Ilmu Komunikasi Universitas Padjadjaran (Fikom Unpad) kepada berbagai sumber informasi lainnya, baik itu dengan menggunakan media berbasis teknologi komunikasi dan informasi maupun dengan melakukan forum diskusi bersama rekan sejawat dikampusnya. Proses pendalaman informasi dilakukan melalui empat tahapan besar yaitu tahap permulaan pencarian informasi, proses mengakses LINE@ BEM Fikom Unpad untuk mendapatkan informasi, proses pendalaman informasi dengan melakukan pencarian kepada sumber rujukan lain, dan penggunaan informasi yang telah mereka peroleh dari hasil pendalaman informasi. Penelitian ini menggunakan metode Kualitatif dengan tradisi Fenomenologi (Wawancara, observasi, dan dokumentasi).

Dalam penelitian ini, penulis fokus membahas mengenai bagaimana penggunaan layanan perpustakaan digital openlibrary dalam memenuhi kebutuhan informasi mahasiswa Telkom University.

Mengingat beragamnya inovasi penyajian informasi serta fasilitas kemudahan akses yang disediakan, peneliti merasa tertarik pada tema yang diangkat terkait penggunaan layanan perpustakaan digital open library. Penggunaan disini ditujukan lebih kepada civitas akademika yang tak lain merupakan mahasiswa Telkom University. Maka dari itu sesuai realita dilapangan, timbul pertanyaan terkait yakni bagaimana penggunaan layanan perpustakaan digital open library dalam memenuhi kebutuhan informasi mahasiswa Telkom University.

\section{METODE PENELITIAN}

Metode yang digunakan dalam penelitian ini adalah metode kualitatif dengan pendekatan studi kasus. Studi kasus merupakan suatu inkuiri empiris 
yang menyelidiki fenomena di dalam konteks kehidupan nyata, bilamana batas-batas fenomena dan konteks tidak tampak dengan tugas dan dimana multi sumber bukti dimanfaatkan (Yin, 2008). Dalam hal ini penulis melakukan penyelidikan mengenai fenomena dalam penggunaan layanan perpustakaan digital open library dalam memenuhi kebutuhan informasi mahasiswa Telkom University.

Subjek penelitian adalah sebagai informan, yang artinya orang pada latar penelitian yang dimanfatkan untuk memberikan informasi tentang situasi dan kondisi latar penelitian atau dengan kata lain subjek penelitian adalah orang orang yang diamati sebagai sasaran penelitian (Moleong, 2004).

Adapun yang menjadi subyek dalam penelitian ini adalah Mahasiswa Telkom University. Subjek disini dipilih sebagai informan yang memberikan informasi dilapangan mengenai situasi dan kondisi yang terjadi. Peneliti menggunakan tekhnik sampling untuk menentukan informan yang diwawancarai secara purposive sampling, yang merupakan tekhnik pengambilan sampel sumber data dengan pertimbangan tertentu. Pertimbangan tertentu yang dimaksud dalam penelitian ini yaitu mahasiswa Telkom University yang telah mengakses dan menggunakan layanan open library ini minimal 3 kali dalam seminggu.

Dalam menentukan informan, peneliti menyebarkan form penelitian untuk 40 orang di perpustakaan open library Telkom University pada 2 Februari 2017. Setelah itu peneliti menentukan beberapa orang yang akan dijadikan informan sesuai dengan jawaban dari form penelitian yang telah disebarkan. Untuk data awal peneliti menetapkan informan sejumlah 10 orang, akan tetapi peneliti tidak terpaku kepada 10 orang tersebut, melainkan dari penemuan data lapangan yang telah menunjukkan titik jenuh maka peneliti mengakhiri sesi penelitian dan wawancara.

Dalam penelitian ini penulis menggunakan dua sumber data yaitu sumber data primer dan sumber data sekunder. Data primer, yaitu data yang dikumpulkan langsung oleh peneliti dari sumber utamanya, misalnya mahasiswa Telkom University dan staf perpustakaan open library Telkom University. Sedangkan data sekunder yaitu data yang langsung dikumpulkan oleh peneliti sebagai penunjang dari sumber pertama, misalnya data yang didapat dari perpustakaan tersebut ataupun data yang berkaitan dengan penelitian ini.

Teknik pengumpulan data yang digunakan peneliti untuk mendapatkan data-data yang diperlukan adalah (1) Observasi. Peneliti memperoleh informasi melalui pengamatan secara langsung terhadap siatuasi dan kondisi di lapangan untuk mengetahui gambaran data mengenai proses pencarian informasi yang dilakukan oleh mahasiswa Telkom University. Dengan melakukan observasi dan pengamatan, peneliti dapat melihat dan mencatat perilaku dan kejadian sesuai dengan yang terjadi dilapangan. Kegiatan observasi juga dapat memungkinkan peneliti untuk dapat melihat fenomena sebagaimana yang dilihat oleh subjek penelitian dan merasakan apa yang dirasakan oleh subjek penelitian. (2) Wawancara. Pada 
penelitian ini, wawancara dilakukan dengan para informan yang merupakan mahasiswa Telkom University yang sedang beraada di perpustakaan open library dan yang pernah mengakses layanan digital open library Telkom University. Tekhnik wawancara bertujuan untuk mengetahui proses pencarian informasi yang dilakukan melalui layanan open library ini. (3) Dokumentasi. Peneliti melakukan pendokumentasian pada saat melakukan wawancara dengan pengambilan rekaman suara dan melakukan foto bersama serta catatan dari hasil wawancara dengan narasumber. (4) Studi Kepustakaan. Studi pustaka dalam penelitian ini, penulis lakukan dengan mengumpulkan dan membaca-baca buku terkait metode penelitian kualitatif, sumber elektronik atau jurnal elektronik tentang perilaku pencarian informasi, dan sebagainya.

Triangulasi. Wiersma menyatakan bahwa Triangulasi dalam pengujian kredibilitas ini diartikan sebagai pengecekan data dari berbagai sumber dengan berbagai cara, dan berbagai waktu (Sugiyono, 2010). Dengan demikian terdapat triangulasi sumber, triangulasi teknik, dan triangulasi waktu. Dalam hal ini, peneliti menggunakan triangulasi sumber, yang berarti untuk mendapatkan data peneliti mendapatkan sumber yang berbedabeda dengan tekhnik yang sama. Peneliti memerlukan teknik wawancara kepada ahli yang tahu tentang penggunaan layanan perpustakaan digital open library Telkom University.

\section{HASIL DAN PEMBAHASAN}

Perpustakaan open library mengambil konsep 'Green Futuristik' artinya perpus-takaan modern yang mengantisipasi kemajuan teknologi ataupun sistem pendidikan di masa depan. Terdapat tiga komponen yang menjadi pembeda perpustakaan open library Telkom University dengan perpustakaan lain diantaranya adalah tempat, konten, dan layanan.

Open library Telkom Univesity menyajikan 113.357 koleksi buku fisik, dan e-book yang jumlahnya lebih banyak dari itu, serta layanan yang diperuntukan bagi masyarakat umum. Perpustakaan open library Telkom University ini merupakan salah satu sarana pendukung dan penunjang dalam menyediakan berbagai informasi yang dibutuhkan untuk melaksanakan Tri Dharma Perguruan Tinggi, yaitu Proses Belajar Mengajar, Penelitian, dan Pengabdian Masyarakat. Perpustakaan Telkom University dikembangkan sebagai Knowledge Management Center yang senantiasa memastikan ketersediaan koleksi pustaka kurikuler, koleksi pustaka pendukung riset, koleksi pustaka wawasan umum dan sastra, koleksi pustaka kebangsaan, koleksi pustaka wawasan global, dan lain-lain, dengan jumlah judul pustaka dan jumlah koleksi minimal yang sesuai ketentuan Standar Nasional Pendidikan Tinggi (SNPT).

Perpustakaan digital open library merupakan kolaborasi dari sebuah sistem informasi perpustakaan dan sistem knowledge management. Layanan perpustakaan digital open library disini berfungsi sebagai alat telusur atau katalog online (OPAC) untuk fasilitas pencarian serta 
digunakan sebagai manajemen informasi perpustakaan. Sebagai bentuk dari perpustakaan digital, layanan library online ini memberikan kemudahan akses dalam menelusuri berbagai koleksi dan referensi yang disediakan perpustakaan, serta kemudah-an dalam melakukan transaksi yang biasa dilakukan di perpustakaan secara online, seperti ruang diskusi, perpanjangan pinjaman secara mandiri dan cek denda keterlambatan. Perpustakaan digital open library disediakan bagi seluruh pengguna khusunya civitas akademika dengan tujuan untuk memudahkan pengguna dalam menemukan informasi dan sumber referensi yang dibutuhkan.

Penjelajahan diawali dengan autentikasi menggunakan akun SSO (Igracias), dan pencarian informasi dimulai dengan menggunakan fasilitas pencarian sederhana. Mahasiswa pun memanfaatkan internet untuk mengakses berbagai sumber lain dengan mesin pencari google untuk lebih memperkaya informasi yang dibutuhkan. Pada tahap perumusan, mahasiswa melakukan brainstorming dengan mempelajari dan memahami proses penyelesaian masalah terkait topik yang sesuai dan mendiskusikannya kepada teman, dosen, atau orang yang dianggap paham dan bisa diajak diskusi terkait topik yang sedang diperdalam. Tahap pengumpulan dilakukan dengan mengunduh file dan menyimpannya di folder laptop mereka. Pada tahap penyajian mahasiswa Telkom University akan merasa puas setelah mendapatkan informasi sehingga memungkinkan untuk melakukan monitoring. Penyajian dilakukan dalam bentuk penulisan dokumen baru atau sebagai pelengkap baik dalam penyelesaian tugas perkuliahan (proposal dan makalah) maupun penulisan karya ilmiah (skripsi/TA).

Dipaparkan dalam gambar 1 mengenai tahapan penggunaan layanan perpustakaan digital open library.

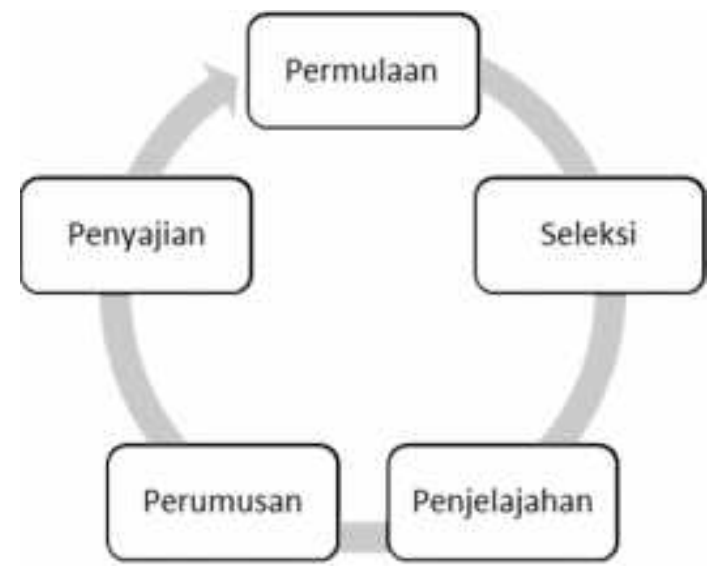

Gambar 1. Model tahapan penggunaan layanan perpustakaan digital open library Sumber: hasil penelitian, 2017

Penggunaan layanan perpustakaan digital open library oleh mahasiswa Telkom University dilakukan melalui 6 tahapan besar yaitu permulaan, pemilihan informasi, penjelajahan informasi, perumusan informasi serta tahapan penyajian informasi.

Permulaan penggunaan di latarbelakangi oleh alasan, motif dan tujuan dari mahasiswa Telkom University untuk mendapatkan informasi. Peneliti melakukan pencarian informasi awal dari informan tentang alasan mengapa para mahasiswa tersebut menggunakan dan mengakses layanan perpustakaan digital open library. Alasan mahasiswa mengakses dan menggunakan layanan open library dikarenakan layanan tersebut merupakan fasilitas yang dikelola dan disediakan langsung oleh open library Telkom University. Disamping memiliki manfaat dan fasilitas yang beragam, layanan Perpustakaan digital open library memudahkan mahasiswa dalam melakukan proses pencarian informasi atau 
sumber referensi yang dibutuhkan seperti mencari buku, penelitian terdahulu (skripsi) yang tersedia dalam bentuk flippingbook, memudahkan dalam pencarian letak buku, serta dapat digunakan untuk pemesanan ruang diskusi, cek plagiat, dan segala informasi yang sedang dibutuhkan. Motivasi dan tujuan tersebut berkembang karena adanya kesadaran dari dalam diri terkait kebutuhan terhadap informasi seperti mendapatkan sumber referensi dalam menyelesaikan tugas perkuliahan maupun tugas akhir. Sedangkan motif yang timbul terkadang berasal dari diri sendiri maupun dari orang lain seperti karena dorongan dari teman atau dosen. Sondang P Siagian dalam buku Teori Motivasi dan Aplikasinya menjelaskan bahwa ada 3 komponen utama dalam motivasi, yaitu adanya kebutuhan, dorongan dan tujuan. (Khadijah, Rejeki, Anwar, \& Sukaesih 2016). Motif informan mengakses layanan Perpustakaan digital open library karena adanya dorongan dari diri terkait kebutuhan, kesadaran, dan keinginan untuk memenuhi kebutuhan informasi serta pengetahuannya baik dalam dalam menyelesaikan tugas perkuliahan maupun skripsi. Adanya motif yang timbul tentunya disertai dengan tujuan tertentu. Tujuan mereka adalah untuk menambah pengetahuan dan wawasan, menambah referensi, dan menunjang perkuliahan baik itu tugas perkuliahan maupun tugas akhir, lalu menggunakan layanan digital open library juga dikarenakan subjek keilmuan dan pengetahuannya sesuai.

\begin{tabular}{llr}
\multicolumn{1}{c}{ Tahap } & \multicolumn{1}{c}{ selanjutnya } & adalah \\
pemilihan & (seleksi). & Dalam \\
penggunaannya, & mahasiswa & Telkom \\
University akan & me-lakukan & seleksi \\
informasi, artinya & mereka akan memilih
\end{tabular}

informasi sesuai dengan minat dan topik yang sedang mereka butuhkan. Dalam penelitian ini hampir seluruh tahap dilalui aspek seleksi. Proses dalam memilih informasi dilakukan dengan cara mengidentifikasi topik yang sedang dibutuhkan, serta melakukan seleksi dengan cara membaca abstrak dan judul terlebih dahulu. Dalam mengakses layanan Perpustakaan digital open library, media yang digunakan cukup beragam akan tetapi mayoritas mengungkapkan lebih menyukai menggunakan laptop pribadi karena tampilannya yang lebih lengkap dan nyaman sedangkan lokasi akses dapat dilakukan dimana saja, baik itu dirumah, kampus, perpustakaan, maupun diluar Telkom University. Hal ini menjadi bagian dari salah satu kelebihan yang didapat oleh pengguna khususnya mahasiswa Telkom University dalam hal kemudahan akses yang mana digital library dapat diakses dimanapun dan bersifat satu pintu akses.

Tahap Penjelajahan dilakukan dalam bentuk browsing atau perilaku akses dengan cara masuk ke link Perpustakaan digital open library dan log in dengan menggunakan akun SSO atau Igracias. Pencarian dilakukan dengan memasukkan kata kunci berdasarkan subjek atau topik yang dicari pada kolom search/pencarian sederhana dengan menggunakan laptop pribadi, handphone, atau personal computer perpustakaan. Adapun cara untuk mengakses layanan perpustakaan digital open library ini dapat dilakukan dengan mudah. Pengguna hanya cukup melakukan proses otentikasi sekali saja untuk mendapatkan izin full akses terhadap layanan yang ada di perpustakaan digital open library. Strategi penelusuran yang dilakukan berdasarkan dua katagori yaitu penelurusan secara 
mandiri dan meminta bantuan orang lain (pustakawan/staff perpustakaan). Pada tahap ini mahasiswa Telkom University akan melakukan penelusuran pada berbagai sumber informasi lain, mahasiswa Telkom University pun akan memanfaatkan internet atau mengakses google untuk mencari e-book, e-journal, serta mengunjungi website tertentu dan Perpustakaan digital perguruan tinggi lain. Hal ini dilakukan semata-mata untuk dapat memperkaya informasi dan referensi yang didapat. Pada tahap ini, mahasiswa Telkom University mengalami beberapa hambatan, dimana mayoritas hambatan yang dialami adalah jaringan koneksi internet dan kesulitan dalam penelusuran pada rak koleksi. Selanjutnya dalam tahap penjelajahan (exploration) mahasiswa Telkom University cenderung mengakses google termasuk google cendekia untuk menelusuri sumber lain dalam mencari informasi yang sedang dibutuhkan, baik berupa jurnal, paper, artikel, atau bahkan e-book. Sumber informasi yang digunakan pun beragam seperti dari google dengan kriteria adanya issn, sumber yang umum digunakan mahasiswa, dan rekomendasi dari dosen. Tak hanya itu mereka juga mengungkapkan sering mengakses dan mengunjungi website perpustakaan online perguruan tinggi lainnya.

Dalam tahap perumusan, mahasiswa Telkom University akan mencoba me-mahami rumusan dan cara penyelesaian masalahnya sesuai dengan teori, selain itu dalam rangka memperdalam pemaha-mannya terkait informasi yang didapat, mahasiswa Telkom University akan membahasnya kedalam forum diskusi (brainstorming) dan bertanya langsung kepada pihak yang dianggap lebih mengerti dan lebih paham seperti teman, senior, atau dosen. Dalam melakukan penelusurannya mahasiswa Telkom University akan menyimpan informasi yang didapat dengan cara mengunggah file tersebut dalam bentuk $p d f$ dan menyimpannya di folder laptop mereka. Setelah melakukan proses-proses diatas atas dan mencari ke berbagai sumber informasi lainnya, maka akan timbul rasa kepuasaan tersendiri pada diri mahasiswa Telkom University. Rasa puas tersebut timbul karena mahasiswa Telkom University memperoleh manfaat dari informasi yang didapat, yaitu memenuhi kebutuhan informasi mereka terkait topik yang sedang mereka butuhkan, baik untuk sekedar menambah pengetahuan, melengkapi tugas perkuliahan maupun menyelesaikan tugas akhir atau skripsi. Informasi yang didapat disajikan dalam bentuk penulisan ulang di dokumen baru (karya tulis, tugas akademik, tugas akhir/skripsi/proposal) dan terkadang mahasiswa Telkom University melakukan paraprashing dalam proses penyajian atas informasi yang didapat. Secara umum, penggunaan layanan perpustakaan digital dapat memenuhi kebutuhan kognitif, integrasi personal dan integrasi sosial mahasiswa Telkom University sedangkan secara khusus penggunaan layanan perpustakaan digital open library dapat memenuhi kebutuhan informasi rutin, mutakhir, mendalam dan sekilas.

Tahap selanjutnya adalah

Pengumpu-lan (koleksi). Tahap ini merupakan tahap dimana informan mulai melakukan koleksi atau tindakan mengumpulkan informasi yang diperolehnya. Informan menyatakan bahwa informasi yang mereka dapatkan disimpan dengan cara di download dan disimpan dalam laptop pribadinya, 
terkadang informasi yang didapat dari buku disimpan dengan cara difoto pada bagian yang penting untuk nantinya digunakan dalam dokumen baru. Melalui layanan digital open library yang menampung barbagai format elektronik termasuk koleksi digital, maka pengguna dapat mengambilnya dengan mengunduh dari server dan menyimpan di laptop pribadinya, selain itu informan juga menambahkan bahwa terkadang ia simpan di bookmarks agar mudah dalam proses temu kembali.

Pada tahap penyajian, hasil dari proses-prosesnya akan menimbulkan rasa kepuasaan tersendiri pada diri mahasiswa Telkom University, sehingga ada kemungkinan mahasiswa Telkom University akan melakukan tindakan monitoring. Rasa puas tersebut timbul karena mahasiswa Telkom University memperoleh manfaat dari informasi yang didapat, yaitu terpenuhinya kebutuhan akan informasi mengenai topik yang akan mereka bahas untuk menyelesaikan tugas perkuliahannya. Informasi yang didapat disajikan dalam bentuk penulisan ulang di dokumen baru (karya tulis, tugas akademik, tugas akhir/skripsi/proposal) dan terkadang mahasiswa Telkom University melakukan paraprashing dalam proses penyajian atas informasi yang didapat. Rasa puas tersebut timbul karena mereka berhasil mendapatkan manfaat dari proses pendalaman informasi yang mereka lakukan, yaitu untuk mengetahui informasi dari hasil pencarian yang mereka lakukan untuk dapat memperkaya pengetahuan dalam rangka menyelesaikan tugas perkuliahan dikampusnya. Menurut Kuhlthau (1991) dalam (Permana, 2016) situasi seperti ini terdapat pada tahap akhir dari proses pencarian informasi, yaitu tahap presentation. Kuhlthau menyatakan bahwa "In presentation, feelings of relief are common with a sense of satisfaction if the search has gone well or disappointment if it has not. The task is to complete the search and to prepare to present or otherwise use the findings." Dalam konteks ini, mahasiswa Telkom University merasa puas setelah mendapatkan informasi atas hasil dari keberhasilan proses pencarian informasi yang dilakukannya. Rasa puas tersebut berkembang menjadi sebuah tindakan pemanfaatan dan penggunaan informasi yang didapat. Tindakan pemanfaatan atas informasi yang didapat dilakukan dengan menyajikanya dalam bentuk penulisan dokumen baru, pelengkap dalam penulisan karya ilmiah (skripsi dan TA) dalam bentuk karya tulis (Proposal dan makalah). Rasa puas tersebut akan mendorong kemungkinan terjadinya proses monitoring dengan memanfaatkan dan mengakses layanan perpustakaan digital dikemudian hari.

Secara umum penggunaan layanan perpustakaan digital open library dapat memenuhi kebutuhan kognitif (memperkuat atau menambah informasi, pengetahuan, dan pemahamannya terkait subjek tertentu), integrasi personal (memenuhi dan meningkatkan pengetahuannya) atas dasar kesadaran status yang disandangnya sebagai mahasiswa dan integrasi sosial (berinteraksi dan berdiskusi dengan teman sesama mahasiswanya baik di lingkungan kampus sendiri maupun di luar kampusnya).

Sedangkan secara khusus penggunaan layanan perpustakaan digital open library dapat memenuhi kebutuhan informasi rutin (untuk menyelesaikan tugas perkuliahannya di kampus), kebutuhan informasi mutakhir (mendapat- 
kan informasi yang menunjang perkuliahannya sesuai dengan subjek bidang yang digelutinya, dalam hal ini dapat terlihat dengan penggunaan koleksi sumber referensi dan informasi yang disediakan oleh perpustakaan open library), kebutuhan informasi mendalam (penelusuran dan pemanfaatan karya ilmiah atau penelitian terdahulu (skripsi online) guna menambah pengetahuannya dan untuk menyelesaikan tugas akhir. Seperti penggunaan e-journal, review penelitian terdahulu (skripsi online), dan kebutuhan informasi sekilas mahasiswa Telkom University (membaca sumber literatur yang ada hanya sebatas untuk mencari tahu tanpa menggunakan informasi tersebut, misalnya dengan membaca abstrak. Dalam penggunaan fasilitas, kebutuhan disini dapat termasuk dalam melihat informasi ketersediaan koleksi, informasi denda keterlambatan, informasi bibliografi dan informasi letak koleksi atau buku di perpustakaan).

Buckland (1999) dalam bukunya yang berjudul Library Services in Theory and Contex menyatakan teori pelayanan perpustakaan berisi proses pelayanan perpustakaan yang terdiri dari pertanyaan (inquiry), pencarian (retrieval), penerimaan informasi (becoming informed), permintaan (demand) dan alokasi (allocation) (Rukmana, 2015). Inquiry adalah pertanyaan yang diajukan anggota perpustakaan dalam pencarian koleksi. Dalam hal ini, mahasiswa Telkom University dapat meminta bantuan staff perpustakaan jika memiliki kesulitan dalam memnuhi kebutuhannya. Proses selanjutnya adalah retrieval yaitu bahasa pertanyaan yang diajukan dalam pencarian. Mahasiswa Telkom University melakukan pencarian informasi melalui bantuan search engine ataupun bantuan dari staff perpustakaan. Becoming informed berkaitan tentang alur informasi yang terjadi setelah dilakukan pencarian koleksi. Setelah melakukan pencarian informasi, mahasiswa Telkom University mendapatkan informasi yang dibutuhkan. Demand merupakan kebutuhan akan pelayanan perputakaan yang dapat memuaskan anggota perpustakaan. Dalam hal ini mahasiswa Telkom University memiliki kebutuhan yang berbeda satu sama lain tetapi staff perpustakaan selalu dapat memnuhi kebutuhan tersebut. Tahapan terakhir adalah allocation merupakan bagian dari manajemen layanan perpustakaan. Staff perpustakaan Telkom University mencoba membuat pengaturan dan capaian yang akan dituju oleh perpustakaan dalam hal memenuhi kebutuhan informasi mahasiswa Telkom University.

Perpustakaan digital Telkom University menyatukan berbagai fitur seperti e-learning, pencarian data katalog (OPAC), informasi berupa fitur berita/event/seminar yang berkaitan dengan perpustakaan, e-proceeding, display koleksi terbaru, ulasan terhadap koleksi, sirkulasi seperti fitur pemesanan buku, fitur perpanjangan peminjaman buku (mengontrol peminjaman secara mandiri), navigasi yang memungkinkan pengguna terhubung ke link media sosial yang dimiliki oleh perpustakaan open library Telkom University, dan ask librarian yang menginformasikan pengguna dengan mudah menghubungi petugas untuk berbagai keperluan. Disamping itu, layanan ini menyediakan koleksi digital tugas akhir yakni akses skripsi online yang tersedia dalam bentuk flipping book, akses ke e-journal, e-book, e-magazine, e-proceeding, upload karya ilmiah atau tugas akhir secara mandiri, reservation ruang diskusi, 
informasi mengenai iThenticate atau tools cek plagiat. Layanan tersebut juga merupakan wadah untuk berbagi pengetahuan dengan cara memberi ulasan atau komentar terhadap karya karya yang di upload dalam bentuk flippingbook di website open library.

\section{SIMPULAN}

Dari hasil penelitian dapat disimpulkan bahwa keseluruhan mahasiswa Telkom University melalui enam tahapan proses pencarian informasi dalam penggunaa layanan Perpustakaan digital open library. Tahapan tersebut adalah permulaan, penjelajahan, perumusan dan pengumpulan, penyajian dan pemilihan. Penulis menemukan bahwa dalam prosesnya satu aspek dengan yang lainnya saling berkaitan dan melengkapi, sehingga tahapan pencarian informasi dapat berubah urutannya sesuai di lapangan. Urutan didalamnya dapat berubah dan saling melengkapi dimana aspek yang paling menonjol adalah seleksi. Hampir pada setiap tahap yang ada, mahasiswa melakukan tindakan seleksi didalamnya.

Layanan perpustakaan digital open library sebagai fasilitas di perpustakaan yang berfungsi sebagai media penelusuran informasi dan mempermudah transaksi di perpustakaan Telkom University. Saran dari peneliti ada baiknya jika tampilan dan fungsinya lebih dioptimalkan lagi. Selain itu dalam rangka mengoptimalkan penggunaan perpustakaan digital, akan lebih baik lagi bila pihak perpustakaan lebih sering dalam melakukan kegiatan sosialisasi kepada pemustaka atau pengguna khususnya kepada civitas akademika. Sosiaslisasi dapat dilakukan dalam bentuk pelaksanaan pendidikan pemakai, baik dalam rangka sosialisasi fasilitas yang dimiliki maupun program literasi informasi, misalnya strategi dalam penelusuran informasi hingga pemanfaatan e-resources yang dilanggan oleh open library Telkom University.

\section{DAFTAR PUSTAKA}

Herni. (2016). Penggunaan aplikasi single Sign-on dalam memenuhi kebutuhan informasi mahasiswa Fakultas Peternakan Universitas Padjadjaran. (Skripsi). Universitas Padjadjaran, Sumedang.

Kamus Besar Bahasa Indonesia (KBBI). (2017). Retrieved February 12, 2017, from https://kbbi.web.id/guna

Khadijah, U. L. S, Rejeki, D. S., Anwar, R. K \& Sukaesih. (2016). Literasi informasi dalam menumbuhkan motivasi berwirausaha bagi para ibu rumah tangga di kelurahan Nagasari kabupaten Karawang Barat. Jurnal Kajian Informasi \& Perpustakaan, 4(2), 149-160.

Moleong, L. J. (2004). Metode kualitatif. Bandung: Remaja Rosdakarya.

Permana, A.N. (2016). Proses pendalaman informasi berbasis informasi awal dari LINE @BEM Fikom Unpad oleh mahasiswa. (Skripsi). Universitas Padjadjaran, Sumedang.

Rukmana, E. N, Yusup, P. M. \& Damayani, N. A. (2015). Kegiatan pelayanan perpustakaan di Perpustakaan Batu Api (studi kasus mengenai proses pelayanan perpustakaan dan jenis pelayanan di Perpustakaan Batu Api). Jurnal Kajian Informasi \& Perpustakaan, 3(2), 235-252. https://doi.org/http:/ /dx.doi.org/10 .24198/jkip.v3i2.10000

Sasongko, D \& Hartanto, R. (2015). Evaluasi perpustakaan digital perguruan tinggi berdasarkan karakteristik perpustakaan digital. In Prosiding SNST Fakultas Teknik. Semarang. Retrieved from https:// publikasiilmiah.unwahas.ac.i d/index.php/PROSIDING_SNST_FT 
/article/view/1189

Sugiyono. (2010). Metode penelitian kualitatif, kuantitatif $\mathcal{E}$ RND. Bandung: Alfabeta.

Sulistyo-Basuki. (2001). Pengantar ilmu perpustakaan. Jakarta: Gramedia Pustaka.
Yin, R. K. (2008). Studi kasus: desain dan metode. (Mudzakir, Ed.). Jakarta: Raja Grafindo Persada.

Yusup, P. M. (2010). Teori dan praktik penelusuran informasi (information retrieval). Jakarta: Kencana. 